\title{
DIRECTIONAL FLORAL ORIENTATION IN JOSHUA TREES (YUCCA BREVIFOLIA)
}

\author{
Steven D. Warren ${ }^{1}$, L. Scott Baggett ${ }^{2}$, and Heather Warren ${ }^{3}$
}

\begin{abstract}
Joshua tree (Yucca brevifolia Engelm.) is a large, arborescent member of the yucca genus. It is an endemic and visually dominant plant in portions of the Mojave Desert, USA. We document the unique and heretofore unreported directional orientation of its flower panicles. The flower panicles grow primarily at the tips of branches that are oriented to the south. When branches with flower panicles are not oriented in a southerly direction, the flower panicles themselves tend to bend or tilt toward the south. This strategy maximizes exposure of the panicles to direct solar radiation, which, within the latitudes where the Joshua tree grows, is always from the south. Such a strategy may minimize the energetic cost of translocating photosynthates from the plant's leaf rosettes to the flowers. The flower panicles create large, light-colored landing pads for the obligate nocturnal moth pollinator. Residual warmth in the flower panicles may provide a thermal reward for the moth pollinator that emerges shortly after sunset.
\end{abstract}

REsumen.—El árbol de Josué (Yucca brevifolia Engelm.) es miembro grande y arborescente del género Yucca. Es una planta endémica y visualmente dominante en partes del desierto de Mojave, EE.UU. Documentamos, por primera vez, la orientación direccional de sus panículas de flores. Las panículas crecen, principalmente, en las puntas de ramas que están orientadas hacia el sur. Cuando las ramas con panículas de flores no se orientan en dirección sureña, las panículas mismas tienden a doblarse o inclinarse hacia el sur. Esta estrategia maximiza la exposición de las panículas a la radiación solar directa que, en las latitudes donde crece el árbol de Josué, es siempre hacia el sur. Esta estrategia puede minimizar el costo energético de la translocación de los fotosintatos entre las hojas y las flores. Las panículas crean plataformas de aterrizaje grandes y pálidas para las polillas nocturnas que son polinizadoras. El calor residual en las panículas puede ofrecer una recompensa térmica para la polilla polinizadora que emerge poco después de la puesta del sol.

CONFLICT OF INTEREST STATEMENT.-The authors declare that there is no conflict of interest regarding the publication of this article.

Joshua tree (Yucca brevifolia Engelm.; Fig. 1) of the Agavaceae family is endemic to the Mojave Desert, USA. Though not a tree in the traditional sense, it has a woody, arborescent or tree-like growth form. It is seldom a numerically dominant species, but its size and unique growth form often make it a visual dominant (Gucker 2006). Joshua trees typically begin branching dichotomously after reaching a height of $1 \mathrm{~m}$ or more (MacKay 2003). During the first few years, new branches tend to extend upward. Thereafter, branches tend to extend outward from the center. The Joshua tree is slow-growing and long-lived (Comanor and Clark 2000, Gilliland et al. 2006). Like most yuccas, the leathery, semievergreen leaves of the Joshua tree are linear or dagger-shaped, with sharp, pointy tips. The leaves are also short relative to other yuccas, hence, the specific epithet brevifolia. Newer leaves are clustered in rosettes near the ends of branches (Rasmuson et al. 1994). Dead leaves persist for a few years, and tend to recurve back onto the branches, giving the plants an armored appearance (Gucker 2006). Flowers emerge in white or cream-colored panicles from among the leaf rosettes at the ends of the branches (Cronquist et al. 1977). After senescence of a flower panicle, 1 to 3 axillary buds may form, followed by new branches (Trelease 1893). Reproduction can be sexual via the moth-pollinated flowers (Baker 1986) or asexual via underground rhizomes (Simpson 1975).

Ehleringer and House (1984) noted that some columnar or barrel cacti in the eastern Mojave Desert of North America tend to tilt or lean to the south, presumably to maximize exposure of flowers, located near the apices of the stems, to direct solar radiation. Because the Mojave Desert lies north of the Tropic of Cancer, the sun is present year-round in the

\footnotetext{
1USDA Forest Service, Rocky Mountain Research Station, Provo, UT. E-mail: swarren02@fs.fed.us

${ }^{2}$ USDA Forest Service, Rocky Mountain Research Station, Fort Collins, CO.
}

${ }^{3}$ Salem, UT. 


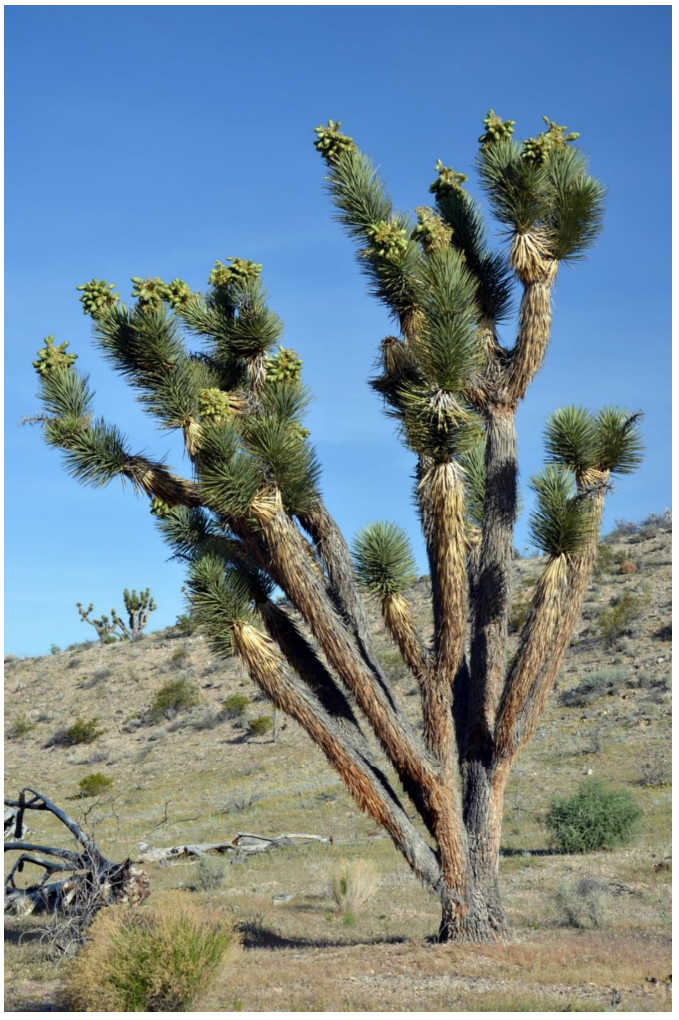

Fig. 1. A Joshua tree in Joshua Tree National Natural Landmark in southwestern Utah, USA. The photograph was taken in a northwesterly direction. Notice that most of the seed pods, which follow blooming, either occur on the south side of the plant or tilt toward the south. The photograph was taken in 2013 after an unusually prolific blooming season. Photo provided courtesy of Lynne Scott of the St. George, Utah, office of the USDI Bureau of Land Management.

south. Although Joshua trees are large desert plants, they are not cacti, and they are arborescent rather than columnar. Their reproductive tissue occurs at the tips of the branches, much like the cacti observed by Ehleringer and House (1984), but they have not been reported to tilt or lean conspicuously. They are, nonetheless, endemic to the harsh desert environment of the Mojave Desert, which is characterized by hot temperatures and aridity. After witnessing strategies used by some plants in the hyperarid Atacama Desert of the Southern Hemisphere to maximize exposure of their flowers to sunlight from the north, we hypothesized that Joshua trees of the Northern Hemisphere might maximize exposure of their flowers to direct sun- light by orienting their flower panicles, located at the ends of branches, toward the south.

We visited a population of Joshua trees in Joshua Tree National Natural Landmark in southwestern Utah. The Joshua tree community is centered at approximately $113^{\circ} 54.7 \mathrm{~W}$ longitude, $37^{\circ} 00.7 \mathrm{~N}$ latitude. These individuals belong to the subspecies Yucca brevifolia jaegeriana and are pollinated by the moth Tegeticula antithetica (Starr et al. 2013). We randomly visited 50 Joshua trees within the population. Upon arriving at each individual, we recorded all flower panicles present. Using a handheld compass, we recorded the cardinal direction toward which the branches with a flower panicle radiated from the central bole of the plant. As some branches were slightly curved, the measurement was made considering the direction of a straight line from the base of the branches to their tips. We also recorded the cardinal direction toward which the flower panicle tilted, if any.

For statistical analyses, von Mises (circular normal) distributions (Mardia and Jupp 2000) were fitted to the branch and flower panicle orientations. Differences in the propensity for flower panicles to orient toward the north or south with respect to the branches were assessed using a cumulative binomial probability. Relationships between the angular distances of the branches from the south with the angular distance of the flower panicles from the branches toward the south were assessed using Spearman's rank correlation. Scatter plots were augmented with locally weighted scatter plot smoothing curves fit to the data (Cleveland 1979). Analyses were completed using the "circular" package of $\mathrm{R}$ version 3.2.2 (C) 2015 R Core Team) and SAS version 9.4 (C) 2014 SAS Institute Inc., Cary, NC).

Although branches of the Joshua trees were distributed semirandomly around the central boles of the plants, the clear majority of branches bearing flower panicles were located on the southern side of the plants (Fig. 2a). The mean orientation of branches bearing flower panicles was south at $186.3^{\circ}$ with a $95 \%$ bootstrapped confidence interval of between $175.6^{\circ}$ and $195.8^{\circ}$. Whether the branches on which they occurred faced the south or not, flower panicles showed a significant affinity for southerly exposure (Fig. 2b). The mean flower panicle orientation was southerly at 

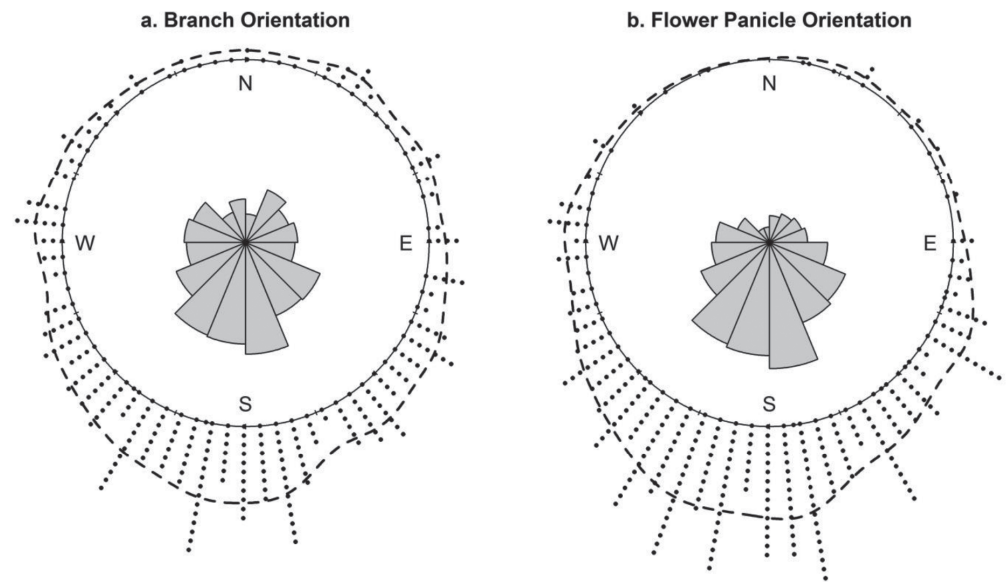

Fig. 2. Circular histograms and smoothed kernel density estimates of the direction in which Joshua tree branches with flower panicles grew relative to the south (a), and the direction in which the flower panicles themselves leaned (b). In both cases, there was a highly significant preference for a southerly exposure, presumably to maximize direct exposure to sunlight.

$184.1^{\circ}$ with a $95 \%$ bootstrapped confidence interval of $177.7^{\circ}$ to $190.4^{\circ}$. Of the 272 branchpanicle pairs, $166(61 \%)$ of the panicles were oriented in the same direction as their supporting branches, 95 (35\%) were oriented more to the south, and only $11(4 \%)$ of the panicles were oriented more to the north than their supporting branches.

When flower-bearing branches occurred in directions that varied from the south, the flower panicles themselves often compensated for the variance by leaning or tilting toward the south. The greater the deviation of the branch from southerly exposure, the greater the compensatory lean by the flower panicles themselves, such that they maximized direct exposure to sunlight (Fig. 3). The result was that the flower panicles increasingly deviated from the directional orientation of the branch on which they were located in order to achieve southerly exposure.

Spearman's rank correlation between the angular distance of the branches from the south and the angular distance of flower panicles from branches toward the south is $\hat{\rho}=0.58$ $(n=272, P<0.0001)$. When pairs were removed in cases where the panicle grew in the same direction as the branch, $\hat{\rho}=0.73$ $(n=106, P<0.0001)$. These significantly positive correlations indicate that the further a branch was oriented away from the south, the more the flower panicle compensated by tilting or leaning toward the south.
Reproduction is energetically expensive, and the amount of energy that an organism can devote to reproduction is limited (Bell 1980), especially where necessary resources are limiting. Plants growing in harsh environments cannot afford the energetic expense of producing structures that do not contribute to their successful growth and reproduction (Kunz and Orrell 2004). One should expect plants in arid areas to exhibit a diverse and unique array of adaptations to cope with the harsh environment. Various cacti exhibit structural and morphological strategies that optimize exposure of their reproductive tissue to sunlight (e.g., Ehleringer et al. 1980, Tinoco-Ojanguren and Molina-Freaner 2000, Vázquez-Sánchez et al. 2007, Figueroa-Castro and Valverde 2011). We could find no similar strategies reported in the literature for noncactus species such as Joshua tree.

Widespread reproductive events in Joshua trees have been considered episodic and rare (Maxwell 1971, Esque et al. 2015). It has been suggested that a period of freezing temperatures may be necessary for flower production (Rundel and Gibson 1996), followed by relatively moist springtime conditions (Maxwell 1971). Perhaps, the infrequent nature of blooming in Joshua trees has contributed to the lack of recognition of the unique flower panicle orientation that we document herein. It was only after observing a functionally similar strategy among plants of the hyperarid 


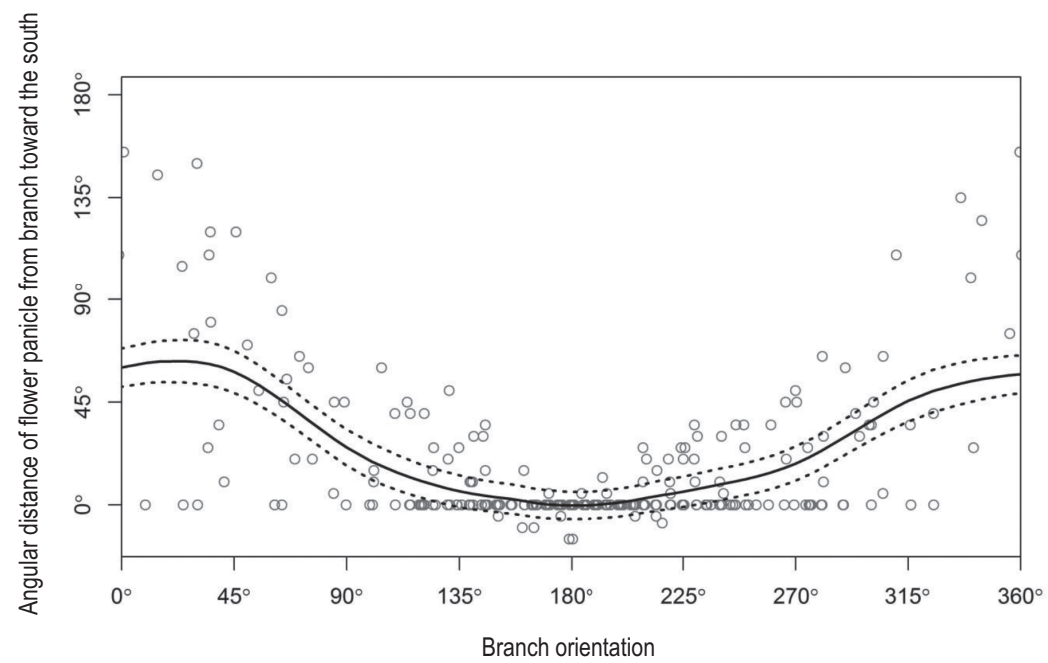

Fig. 3. As the directional growth of Joshua tree branches increasingly varied from a southerly orientation (i.e., $180^{\circ}$ ), the tilt of the flower panicles in a southerly direction also increased, thus increasing direct exposure to sunlight. Shown are smooth (loess) estimates and 99\% confidence intervals.

Atacama Desert of South America, that we decided to search for comparable phenomena in the Mojave Desert of North America.

Other species of plants also orient their flowers toward the sun. Some track the sun's movement through the day, a phenomenon known as heliotropism (e.g., Sherry and Galen 1998). Joshua trees are not heliotropic, but the leaf rosettes at the ends of branches can be considered phototropic, inasmuch as they exhibit growth toward the sun (Whippo and Hangarter 2006). The branches exhibit a significant preference for southern exposure, which maximizes incident sunlight on the leaf rosettes (Rasmuson et al 1994). The previous authors reported higher nitrogen content, greater carbon isotope discrimination, and greater levels of stomatal water conductance in leaf rosettes receiving full sunlight (i.e., those facing the south). A similar conclusion was drawn by Sanford and Huntly (2009) who related enhanced nitrogen content of leaf rosettes to southern orientation. Because the translocation of nutrients and water is energetically expensive (Bloom et al. 1985), especially where such resources are limited, the production of flowers would logically be located in parts of the plant where nutrients are in greatest supply and most efficiently translocated. In Joshua tree, that would be near south-facing terminal leaf rosettes where, coincidentally, the flower panicles also emerge. The flower panicles exhibit even stronger phototropism by tilting or leaning toward sunlight in the south even when the branches do not (Fig. 2).

As the flower panicles themselves show little evidence of chlorophyll or photosynthetic activity, we suggest an additional stimulus for southern exposure. The Joshua tree is exclusively pollinated by small moths of the genus, Tegeticula (Godsoe et al. 2008). The moth emerges at sunset and is active for only a few hours (Pellmyr 1999). Having received abundant sunlight during daylight hours due to their southerly exposure, the flowers likely reradiate warmth for a few hours after sunset when moths are active. This can be important when flowering and pollination take place (March-May; Gucker 2006). We suggest that the warmth serves as an attractant to moths, as demonstrated for other pollinators (Seymour et al. 2003, Rands and Whitney 2008). By retaining warmth as a thermal reward for nocturnal pollinators, yucca flowers may increase the odds of successful pollination and reproduction.

The unusual and open architecture of Joshua tree canopies allows high levels of direct sunlight to sometimes reach leaf rosettes that do not face the south. That would explain why not all of the flower panicles are oriented toward the south, and why they tend to bend or lean toward the south when the branches 
on which they are located are not oriented in that direction. The open, irregular architecture was described by early European explorers to the Mojave Desert as "grotesque," "tormented," and "repulsive" (Kaiser 2014). Despite the irregular arrangement of the canopy, we suggest that the architecture begets energy efficiency and, when coupled with the unique reproductive strategy, contributes to the success of the plant in an otherwise harsh and formidable environment.

\section{Literature Cited}

BAKER, H.G. 1986. Yuccas and yucca moths-a historical commentary. Annals of the Missouri Botanical Garden 73:556-564.

BELL, G. 1980. The costs of reproduction and their consequences. American Naturalist 116:45-76.

Bloom, A.J., F.S. Chapin III, and H.A. Mooney. 1985. Resource limitation in plants-an economic analogy. Annual Reviews of Ecology and Systematics 16: 363-392.

Cleveland, W.S. 1979. Robust locally weighted regression and smoothing scatterplots. Journal of the American Statistical Association 74:829-836.

Comanor, P.L., AND W.H. ClaRk. 2000. Preliminary growth rates and a proposed age-form classification for the Joshua tree, Yucca brevifolia (Agavaceae). Haseltonia $7: 37-46$.

Cronquist, A., A.H. Holmgren, N.H. Holmgren, J.L. Reveal, and P.K. Holmgren. 1977. Intermountain flora: vascular plants of the Intermountain West, U.S.A. Volume 6: The Monocotyledons. Columbia University Press, New York, NY. 584 pp.

Ehleringer, J., AND D. House. 1984. Orientation and slope preference in barrel cactus (Ferocactus acanthodes) at its northern distribution limits. Great Basin Naturalist 44:133-139.

Ehleringer, J., H.A. Mooney, S.L. Gulmon, and P. Rundel. 1980. Orientation and its consequences for Copiapoa (Cactaceae) in the Atacama Desert. Oecologia 46:63-67.

Esque, T.C., P.A. Medica, D.F. Shryock, L.A. DeFalco, R.H. Webb, and R.B. Hunter. 2015. Direct and indirect effects of environmental variability on growth and survivorship of pre-reproductive Joshua trees, Yucca brevifolia Engelm. (Agavaceae). American Journal of Botany 102:85-91.

Figueroa-Castro, D.M., and P.L. Valverde. 2011. Flower orientation in Pachycereus weberi (Cactaceae): effects on ovule production and seed weight. Journal of Arid Environments 75:1214-1217.

Gilliland, K.D., N.J. Huntly, and J.E. Anderson. 2006. Age and population structure of Joshua trees (Yucca brevifolia) in the northwestern Mojave Desert. Western North American Naturalist 66:202-208.

Godsoe, W., J.B. Yoder, C.I. Smith, and O. Pellmyr. 2008. Coevolution and divergence in the Joshua tree/yucca moth mutualism. American Naturalist 171:816-823.

Gucker, C.L. 2006. Yucca brevifolia. In: Fire Effects Information System, U.S Department of Agriculture, Forest Service, Rocky Mountain Research Station, Fire Sciences Laboratory; [accessed 19 August 2015]. http://www.fs.fed.us/database/feis/plants/tree/yucbre/ all.html

KAISER, J. 2014. Joshua tree: the complete guide: Joshua Tree National Park. 5th edition. Destination Press, Chicago, IL. 216 pp.

KunZ, T.H., AND K.S. ORRELL. 2004. Reproduction, energy costs of. Encyclopedia of Energy 5:423-442.

MaCKAY, P. 2003. Mojave Desert wildflowers: a field guide to wildflowers, trees, and shrubs of the Mojave Desert, including the Mojave National Preserve, Death Valley National Park, and Joshua Tree National Park. Wildflower Series. Falcon Guides, Guilford, CT. 338 pp.

Mardia, K.V., AND P.E. Jupp. 2000. Directional statistics. 2nd edition. John Wiley \& Sons Ltd.

Maxwell, C.G. 1971. The tree that is not a tree. American Forests 77(3):4-5.

Pellmyr, O. 1999. Systematic revision of the yucca moths in the Tegeticula yuccasella complex (Lepidoptera: Prodoxidae) north of Mexico. Systematic Entomology 24:243-271.

Rands, S.A., AND H.M. Whitney. 2008. Floral temperature and optimal foraging: is heat a feasible floral reward for pollinators? PLOS ONE 3(4):e2007.

Rasmuson, K.E., J.E. Anderson, and N. Huntly. 1994. Coordination of branch orientation and photosynthetic physiology in the Joshua tree (Yucca brevifolia). Great Basin Naturalist 54:204-211.

Rundel, P.W., And A.C. Gibson. 1996. Ecological communities and processes in a Mojave Desert ecosystem: Rock Valley, Nevada. Cambridge University Press, Cambridge, NY. 369 pp. http://dx.doi.org/10 $.1017 / \mathrm{CBO} 9780511565465$

SANFORD, M.P., AND N. HunTLY. 2009. Selective herbivory by the desert woodrat (Neotoma lepida) on Joshua trees (Yucca brevifolia). Western North American Naturalist 68:164-170.

Seymour, R.S., C.R. White, and M. Gibernau. 2003. Environmental biology: heat reward for insect pollinators. Nature 426:243-244.

Sherry, R.A., AND C. Galen. 1998. The mechanism of floral heliotropism in the snow buttercup, Ranunculus adoneus. Plant, Cell and Environment 21:983-993.

Simpson, P.G. 1975. Anatomy and morphology of the Joshua tree (Yucca brevifolia): an arborescent monocot. Doctoral dissertation, University of California, Santa Barbara, CA. 524 pp.

Stark, T.N., K.E. Gadek, J.B. Yoder, R. Flatz, and C.I. SмIтH. 2013. Asymmetric hybridization and gene flow between Joshua trees (Agavaceae: Yucca) reflect differences in pollinator host specificity. Molecular Ecology 22:437-449.

Tinoco-Ojanguren, C., and F. Molina-Freaner. 2000. Flower orientation in Pachycereus springlei. Canadian Journal of Botany 78:1489-1494.

Trelease, W. 1893. Further studies of yuccas and their pollinators. Missouri Botanical Garden Annual Report 1893:181-226.

VÁzquez-Sánchez, M., T. TerraZas, and S. Arias. 2007. Morphology and anatomy of the Cephalocereus columna-trajani cephalium: why tilting? Plant Systematics and Evolution 265:87-99.

Whippo, C.W., and R.P. Hangarter. 2006. Phototropism: bending towards enlightenment. Plant Cell 18: 1110-1119. 